\title{
Nutritional value of algal diets to clam spat Venerupis pullastra
}

\author{
M. Albentosa ${ }^{1}$, A. Pérez-Camacho ${ }^{1}$, U. Labarta ${ }^{2}$, R. Beiras ${ }^{1}$, M. J. Fernández-Reiriz ${ }^{2}$ \\ ${ }^{1}$ Instituto Español de Oceanografía, Centro Costero de La Coruña, Muelle de Animas s/n, E-15001 La Coruña, Spain \\ ${ }^{2}$ Consejo Superior de Investigaciones Científicas, Instituto de Investigaciones Marinas, Eduardo Cabello, 6, E-36208 Vigo, Spain
}

\begin{abstract}
Clam spat Venerupis pullastra were fed for $4 \mathrm{wk}$ on diets of 2 species of microalgae supplied singly or mixed. Microalgae were Isochrysis galbana and Tetraselmis suecica, species normally used in bivalve hatcheries. Observed growth responses were high for mixed and I. galbana diets and intermediate for the $T$ suecica diet. A slightly higher growth rate was obtained with the mixed diet than with the I. galbana diet. Differences in growth rate were explained by differences in rates of ingestion and digestibility and in the biochemical composition of diets. The intermediate growth rate for spat fed on $T$. suecica was related to lower ingestion rates, lower assimilation efficiencies and lower dietary protein and lipid content. Spat biochemical composition was correlated with growth indices. Lower growth indices were related to lower protein and higher lipid content of spat. The high growth response to the mixed diet was not explained by the factors considered.
\end{abstract}

\section{INTRODUCTION}

One of the major operations in bivalve hatcheries is the production of phytoplankton used as food for broodstock, larvae and spat. Algal culture management is the most costly stage in bivalve seed production (De Pauw 1981).

A number of studies have examined the nutritive value to bivalves of a variety of microalgal species (Walne 1970, Epifanio 1979, Webb \& Chu 1983, Enright et al. 1986a). Generally, bivalve molluscs fed on diets consisting of more than one species of algae grow faster than those fed on single species diets. Moreover, certain algal species considered as 'poor' diets are better utilized in growth when fed in combination with other species of algae (Romberger \& Epifanio 1981).

Although there have been many attempts to correlate differences in mollusc growth with composition of algal species (Wikfors et al. 1984, Enright et al. 1986b), the quantitative and qualitative nutritional requirements of molluscs are still unclear. Some polyunsaturated fatty acids of the $\omega 3$ family have been reported to be essential for the normal growth of certain species of molluscs (Langdon \& Waldock 1981).
In the present work, the nutritional value of 2 microalgal species, Isochrysis galbana and Tetraselmis suecica, to the spat of the bivalve Venerupis pullastra was examined. This study included the effect of diet on spat ingestion rates, growth and biochemical composition. Three diets were evaluated, two composed of single species, and the third composed of a mixture of both species.

\section{MATERIALS AND METHODS}

Spat. Venerupis pullastra spat used in this experiment were obtained from broodstock conditioned in our laboratory. Spawning induction and larval culture were performed following the method described by Pérez Camacho et al. (1977).

From the available stock spat were selected (mean length $1.36 \pm 0.28 \mathrm{~mm}$ ). Live and dry weights of this group were 0.47 and $0.21 \mathrm{mg}$ ind. ${ }^{-1}$, respectively. Ashfree dry weight of the initial spat was $15.3 \%$ of dry weight.

Spat stock was randomly distributed between the experimental cultures, each one containing an initial biomass of $2 \mathrm{~g}$ (live weight). 
Experimental conditions of spat cultures. Spat biomass was placed in partly submerged cylinders, $12 \mathrm{~cm}$ diameter by $7 \mathrm{~cm}$ high, equipped at the bottom with a $400 \mu \mathrm{m}$ nylon mesh. Each cylinder was hung at the surface of 121 plastic tanks $(40 \times 30 \times 20 \mathrm{~cm})$ to a depth of about $10 \mathrm{~cm}$. Seawater, containing suspended food particles, was circulated over the cylinders by air-lift PVC pipes. To avoid food sedimentation, each experimental tank was equipped with an auxiliary air point.

Experimental tanks were maintained at $20 \pm 1{ }^{\circ} \mathrm{C}$. Tanks were emptied, cleaned and refilled with freshly filtered seawater, at a salinity of $33 \%, 3$ times per week. Experimental cultures were maintained for $4 \mathrm{wk}$ when differences in growth between diets could be clearly detected.

Each diet was tested in duplicate; a third control tank without animals was used to quantify food sedimentation.

Diets. Two aigai species, Lsochrysis galbana (T-iso) and Tetraselmis suecica were evaluated singly and in mixed diets. Diets were always in equal relativebiomass proportions on a dry weight basis. The mixed diet was composed of $50 \%$ of each species.

Microalgae were cultured in $6 \mathrm{l}$ glass flasks, in a temperature-controlled chamber at $18^{\circ} \mathrm{C}$ with continuous illumination at 9900 lux. Salinity was constant at $33 \%$. The culture medium has been described by Walne (1966). Algae used in feeding experiments were harvested during the initial stationary phase of growth.

Daily feeding ration, expressed as algal dry weight, applied for all diets was about $5 \%$ of clam live weight. Initial algal concentrations never exceeded $10 \mu \mathrm{g} \mathrm{ml}^{-1}$, pseudofaeces-free food density (Epifanio \& Ewart 1977). Algal cell concentration in the tanks before and after feeding each day was monitored using a Coulter Counter TA II. From these values the number of cells cleared from suspension was calculated so that daily food ration was kept constant. Daily increases in the biomass of the spat were taken into account to adjust food ration. During the first week, daily growth rates were estimated from previous experiments performed in our laboratory.

Dry and organic content of the phytoplankton cells were calculated by filtration through $4.25 \mathrm{~cm}$ Whatman GF/C glass fiber filters previously ashed and rinsed with $0.5 \mathrm{M}$ ammonium formate solution. Filters were dried to constant weight at $80^{\circ} \mathrm{C}$, ashed at $450^{\circ} \mathrm{C}$ in a muffle furnace, and weighed again. Variations in algal dry weight during the experimental period were considered when calculating.

Phytoplankton samples were taken during the 4 wk of the experiments for biochemical analysis. Samples were centrifuged, resuspended with $0.5 \mathrm{M}$ ammonium formate solution, freeze-dried and stored at $-30^{\circ} \mathrm{C}$ until analyzed.
Parameters for diet evaluation. Daily ingestion rates were calculated by the number of cells cleared after the feeding period using the following expression:

$$
I R=\frac{V}{n t}\left(\left(C_{\mathrm{e}_{0}}-C_{\mathrm{e}_{\mathrm{i}}}\right)-\frac{C_{\mathrm{b}_{0}}-C_{\mathrm{b}_{\mathrm{f}}}}{2}\right)
$$

where $I R$ is the ingestion rate expressed in cells ind ${ }^{-1}$ $\mathrm{h}^{-1} ; \quad V$ is the volume of the experimental tank (ml); $n$ is the number of clams; and time $(t)$ is expressed in hours. Initial and final concentrations in the experimental tank are given as $C_{e_{0}}$ and $C_{e_{i}}$ and initial and final concentrations in the control tank as $C_{b_{0}}$ and $C_{b_{\mathrm{f}}}$.

Specific ingestion rates were estimated as the individual ingestion rate divided by the individual dry weight.

Once a week, spat live weight increases for each experimental culture were measured by drying total biomass on absorbent paper for 10 min to remove surface water and then weighing it. Part of the spat were removed and the remainder replaced in the cylinders in such a way that total biomass never exceeded $2 \mathrm{~g}$ (live weight) in any experimental tank. The removed spat were used for dry and organic weight determinations and for biochemical analysis. Dry and organic (ash-free dry weight) weights of spat were determinated at 80 and $450^{\circ} \mathrm{C}$, respectively.

Spat growth during experiments was fitted to the equation:

$$
\text { Dry weight }=e^{k t+\alpha}
$$

where dry weight is expressed in $\mathrm{mg}$ ind ${ }^{-1}$, time $(t)$ in days, and $k_{1} \alpha$ are constants. The constant $k$, which represents the slope of the line, was considered as a coefficient of growth rate and was used for diet comparisons.

Once a week samples from each replicate were taken for measurement of length using a graduated binocular microscope.

Gross growth efficiency $\left(K_{1}\right)$ was considered as the proportion of the organic weight of the food ingested that is incorporated into organic growth of spat, that is

$$
K_{1}=\frac{G}{I}
$$

where $G$ is the increase in organic weight of the spat over a given time period, and $I$ is the organic weight of the food ingested during the same time interval. Net growth efficiency $\left(K_{2}\right)$ was considered as the proportion of the organic matter assimilated - including organic matter incorporated in growth and organic matter consumed in respiration - that is incorporated into organic growth of spat,

$$
K_{2}=\frac{G}{G+R}
$$


where $R$ is the organic weight equivalent of the oxygen consumption of the spat due to respiration. An equal respiration rate was assumed for all diets using a mean value of $2.27 \pm 0.28 \mathrm{ml} \mathrm{O}_{2}\left(\mathrm{~g} \mathrm{AFDW}^{-1} \mathrm{~h}^{-1}\right.$ obtained in our laboratory for Venerupis pullastra spat of the same size and cultured at the same temperature as used in the present experiment (Albentosa et al. unpubl.). For oxygen consumption, we used the ash-free dry weight equivalent given by Walne (1965), namely $1 \mathrm{mg}$ per $1.2 \mathrm{ml} \mathrm{O}_{2}$ consumed.

Assimilation efficiency $(A E)$ was estimated as the proportion of the organic matter ingested that is assimilated, as follows:

$$
A E=\frac{G+R}{I}
$$

Utilization efficiencies of the food protein were calculated following the expression given by De La Higuera et al. (1977),

$$
P P V=\frac{P_{\mathrm{f}}-P_{\mathrm{i}}}{P_{\text {ing }}}
$$

where $P P V$ is the protein productive value, $P_{\mathrm{f}}, P_{\mathrm{i}}$ are the final and initial protein compositions and $P_{\text {ung }}$ is the amount of protein ingested.

Analytical methods. Protein was assayed as described by Lowry et al. (1951) after hydrolysis in $0.5 \mathrm{~N}$ $\mathrm{NaOH}$ for 24 h at $30^{\circ} \mathrm{C}$. Total carbohydrates were quantified as glucose by the phenol-sulphuric acid method (Strickland \& Parsons 1968). Lipids were extracted following a modification of the method of Bligh \& Dyer (1959) (Fernández-Reiriz et al. 1989). Lipids were first extracted with chloroform-methanol (1:2) and after centrifugation the precipitate was extracted again with chloroform-methanol-water $(8: 4: 3)$ (Folch et al. 1957). Total lipids were determined by the Marsh \& Weinstein (1966) method using tripalmitolein standards.

\section{RESULTS}

\section{Growth}

Changes in mean individual spat weights during the $4 \mathrm{wk}$ of the experiment are shown in Table 1. Initial weights were equal for all treatments. Analysis of variance indicated significant effects $(p<0.05)$ of diet on ash-free dry weight of the clams after the second week. Differences were detected after the second week between spat fed on Tetraselmis suecica (TS) and those fed on Isochrysis galbana (ISO) or mixture (MX); however, between the latter 2 diets weight dif- ferences were not significant, even in the third or fourth week ( $p=0.0738$ and $p=0.1156$, respectively).

Dry weight $(D W)$ growth of the clam spat was related exponentially with time (Fig. 1). Regression lines were fitted in the form:

$$
\begin{array}{lll}
\text { ISO: } & D W=\mathrm{e}^{-1.63+(0.114 \pm 0.0024) t} & \mathrm{I}=0.99, \mathrm{p}<0.01 \\
\mathrm{TS}: & D W=\mathrm{e}^{-1.48+(0.090 \pm 0.0067) t} & \mathrm{I}=0.97, \mathrm{p}<0.01 \\
\mathrm{MZ}: & D W=\mathrm{e}^{-1.69+(0.129 \pm 0.0023) t} & \mathrm{I}=0.99, \mathrm{p}<0.01
\end{array}
$$

where $D W$ is expressed as $m g$ ind.$^{-1}$, and $t$ as days. The values in parentheses are $k$ values with their standard errors. Higher values of $k$ represent faster growth

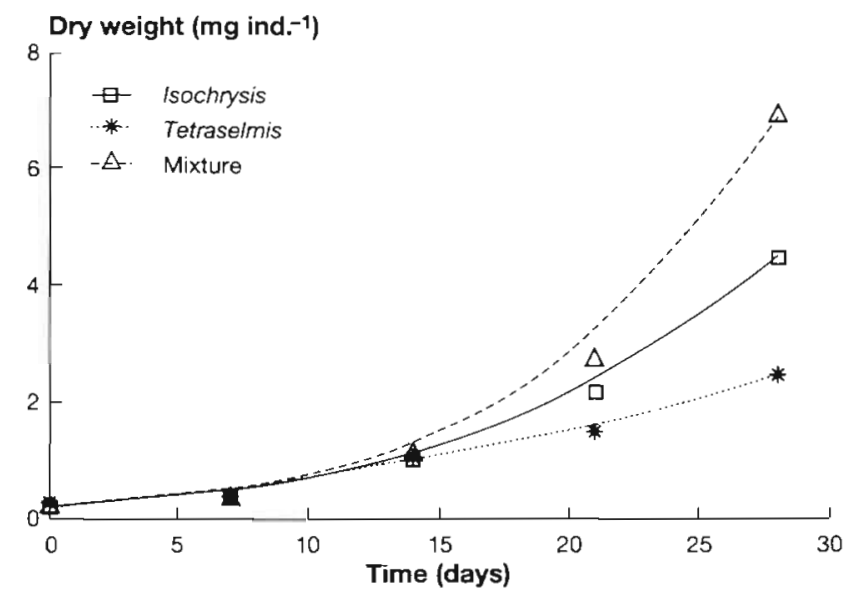

Fig. 1. Venerupis pullastra. Dry weight growth rate of spat fed on Isochrysis galbana, Tetraselmis suecica and a mixture of both microalgae. See the text for regression equations 
Table 2. Venerupis pullastra. Covariance analysis of spat growth fitted between individual dry weight ( $\mathrm{mg}$ ind. ${ }^{-1}$ ) and time (d) for the 3 diets tested, ISO (Isochrysis galbana), TS (Tetraselmis suecica) and MX (I. galbana and $T$ suecica). Degrees of freedom are shown in parenthesis. "Significant differences between $k$ coefficients $(p<0.05)$

\begin{tabular}{|lccr|}
\hline Diet & $F_{\mathrm{v}}(\mathrm{df})$ & $F_{\mathrm{k}}(\mathrm{df})$ & \multicolumn{1}{c}{$F_{\mathrm{a}}(\mathrm{df})$} \\
\hline ISO TS & $0.14(7,7)$ & $11.92(1,14)^{\circ}$ & $5.07(1,16)$ \\
ISO MX & $0.79(7,7)$ & $14.85(1,14)^{\circ}$ & $12.45(1,16)$ \\
TS MX & $5.48(7,7)$ & $29.36(1,14)^{\circ}$ & $10.39(1,16)$ \\
\hline
\end{tabular}

rates. Covariance analyses were performed to compare growth lines; as can be seen in Table 2, F-ratios for the growth rate coefficients $(k)$ were significantly different for all diet comparisons $(p<0.05)$.

Relationship between length $(L)$ and weight of the clam spat was the same for all diets tested ( $p>0.05$ ), so that the regression equation was caiculated with the combined data for the 3 diets,

$$
D W=0.13 L^{2.50} \quad \mathrm{r}=0.96, \mathrm{p}<0.01
$$

where $D W$ is expressed in $\mathrm{mg}$ ind $\mathrm{d}^{-1}$, and $L$ in $\mathrm{mm}$.

Gross growth efficiencies $\left(K_{1}\right)$ were different between diets and showed a remarkable decrease during the experimental period, particularly in the last week. As shown in Fig. 2, after the second week higher growth efficiencies were obtained with MX and ISO than with TS. In Fig. 3 growth efficiencies are plotted against spat weights. For the same spat size, growth efficiencies for TS were notably lower than growth efficiencies for the other diets. Thus, for e.g. $2.5 \mathrm{mg}$ spat, growth efficiency obtained with TS was $20 \%$, whereas with $\mathrm{MX}$ it was $>40 \%$.

Table 3 shows growth and assimilation efficiencies calculated for the overall experiment. Assimilation effi-

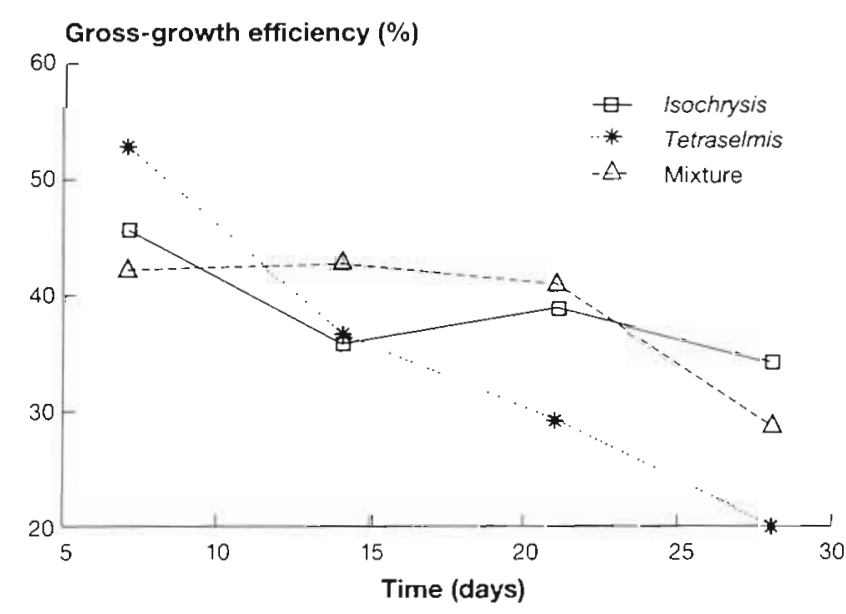

Fig. 2. Venerupis pullastra. Gross growth efficiencies of spat fed on Isochrysis galbana, Tetraselmis suecica and a mixture of both microalgae. Points are the mean values of 2 replicates

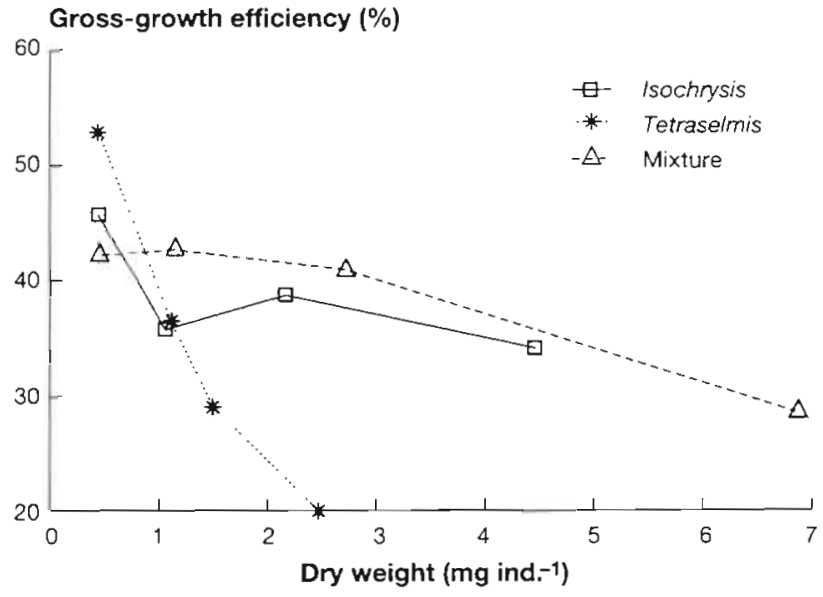

Fig. 3. Venerupis pullastra. Relative-weight gross growth efficiencies of spat fed on Isochrysis galbana, Tetraselmis suecica and a mixture of both microalgae

ciencies ranged from 55 to $70 \%$, similar values to those described by Romberger \& Epifanio (1981) for good and regular diets. In Fig. 4, assimilation efficiencies are plotted against spat dry weight. Assimilation efficiencies for TS decreased during the experiments and were slightly lower than for the other diets, mainly in the last weeks. Between ISO and MX, assimilation efficiencies were quite similar, although in the last week the assimilation efficiency was higher for the ISO diet.

\section{Ingestion rates}

Sedimentation rates observed in the control tanks were negligible for all diets (mean sedimentation rate

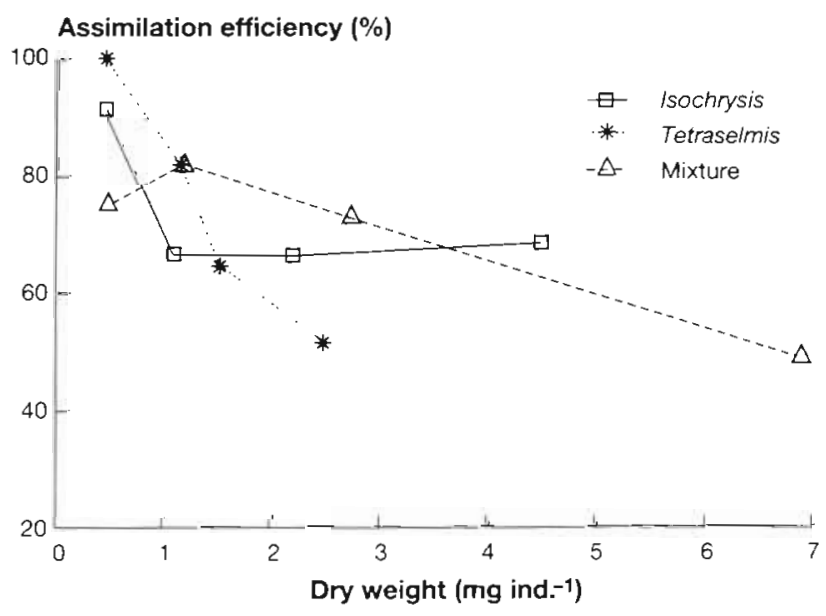

Fig. 4. Venerupis pullastra. Relative-weight assimilation efficiencies of spat fed on Isochrysis galbana, Tetraselmis suecica and a mixture of both microalgae. Assimilation efficiencies were calculated assuming growth increases and respiration costs as assimilated ration 
Table 3. Venerupis pullastra. Efficiencies calculated for the overall experimental period. G: total increase in organic matter per individual; $I$ : total ingestion per individual; $K_{1}$ : gross-growth efficiency; $R$ : respiration cost; $K_{2}$ : net-growth efficiency; $A E$ : assimilation efficiency

\begin{tabular}{|c|c|c|c|c|c|c|}
\hline & $\begin{array}{c}G \\
\left(\mathrm{mg} \mathrm{AFDW}^{-1} \mathrm{ind}^{-1}\right)\end{array}$ & $\frac{I}{\left(\mathrm{mg} \mathrm{AFDW}_{\text {ind }}{ }^{-1}\right)}$ & $\begin{array}{c}K_{1} \\
(G / I)\end{array}$ & $\frac{R}{\left(\text { mg AFDW ind }^{-1}\right)}$ & $\begin{array}{c}K_{2} \\
{[G /(G+R)]}\end{array}$ & $\begin{array}{c}A E \\
{[(G+R) / I]}\end{array}$ \\
\hline ISO & $\begin{array}{l}1.20 \\
(0.13)\end{array}$ & $\begin{array}{l}2.72 \\
(0.05)\end{array}$ & $\begin{array}{l}44.0 \\
(4.2)\end{array}$ & $\begin{array}{c}0.67 \\
(0.08)\end{array}$ & $\begin{array}{l}64.1 \\
(0.28)\end{array}$ & $\begin{array}{l}68.7 \\
(6.9)\end{array}$ \\
\hline TS & $\begin{array}{c}0.55 \\
(0.12)\end{array}$ & $\begin{array}{l}1.54 \\
(0.35)\end{array}$ & $\begin{array}{l}35.5 \\
(0.4)\end{array}$ & $\begin{array}{c}0.39 \\
(0.05)\end{array}$ & $\begin{array}{l}58.4 \\
(2.26)\end{array}$ & $\begin{array}{l}60.8 \\
(2.9)\end{array}$ \\
\hline $\mathrm{MX}$ & $\begin{array}{c}1.62 \\
(0.19)\end{array}$ & $\begin{array}{c}4.33 \\
(0.33)\end{array}$ & $\begin{array}{l}37.1 \\
(1.4)\end{array}$ & $\begin{array}{c}0.86 \\
(0.03)\end{array}$ & $\begin{array}{l}65.2 \\
(1.9)\end{array}$ & $\begin{array}{l}57.2 \\
(0.8)\end{array}$ \\
\hline
\end{tabular}

during the 4 wk was below $5 \%$ of the initial cell concentration), so they were omitted from the ingestion rate calculations (Eq. 1).

Ingestion rates of the clams were mainly dependent on spat weight and could be described by the following expressions:

\section{Gross biochemical composition}

Results obtained from biochemical analysis of the phytoplankton used as food in the experiments are shown in Table 4. For MX, biochemical composition was considered as the mean composition of the single diets.

ISO: $I R=2.92 D W^{1.01} \mathrm{r}=0.97, \mathrm{p}<0.01$

TS: $\quad I R=1.88 D W^{1.09} \quad \mathrm{r}=0.83, \mathrm{p}<0.01$

$\mathrm{MX}: I R=3.00 D W^{1.16} \mathrm{r}=0.97, \mathrm{p}<0.01$

where $I R$ is expressed in $\mu \mathrm{g}$ AFDW ingested ind. ${ }^{-1} \mathrm{~h}^{-1}$, and $D W$ as $\mathrm{mg}$ ind $\mathrm{I}^{-1}$. From these regression lines (Fig. 5), it can be seen that ingestion rate for TS was slightly lower than for the others. Regression lines for ISO and MX diets were almost congruent. Specific ingestion rates [sIR, $\mu \mathrm{g}$ AFDW ingested (mg spat $D W)^{-1} \mathrm{~h}^{-1}$ ] calculated daily were compared by an analysis of variance. The $s I R$ were significantly different $(p<0.01)$ among diets, except for the ingestion rates recorded during the second week of the experiment. These differences were detected between TS and ISO or MX diets; for the latter, significant differences $(p<0.01)$ were only observed in the last week, when sIR for MX were higher with a mean value of $4.11 \mu \mathrm{g}$ AFDW $(\mathrm{mgDW})^{-1} \mathrm{~h}^{-1}$ compared to 3.08 for ISO. Mean SIR for the $4 \mathrm{wk}$ were: 2.11 for TS, 2.98 for ISO and 3.20 for MX.

In $\mathrm{MX}$, it was observed that the ingestion of Isochrysis galbana cells was significantly $(p<0.01)$ higher than that of Tetraselmis suecica, except for the fourth week when no selective ingestion was detected $(p>0.05)$. Mean ingestion values for each microalgal species were $1.37 \mu \mathrm{g}$ AFDW (mg DW) ${ }^{-1} \mathrm{~h}^{-1}$ for $T$. suecica and 1.83 for I. galbana.

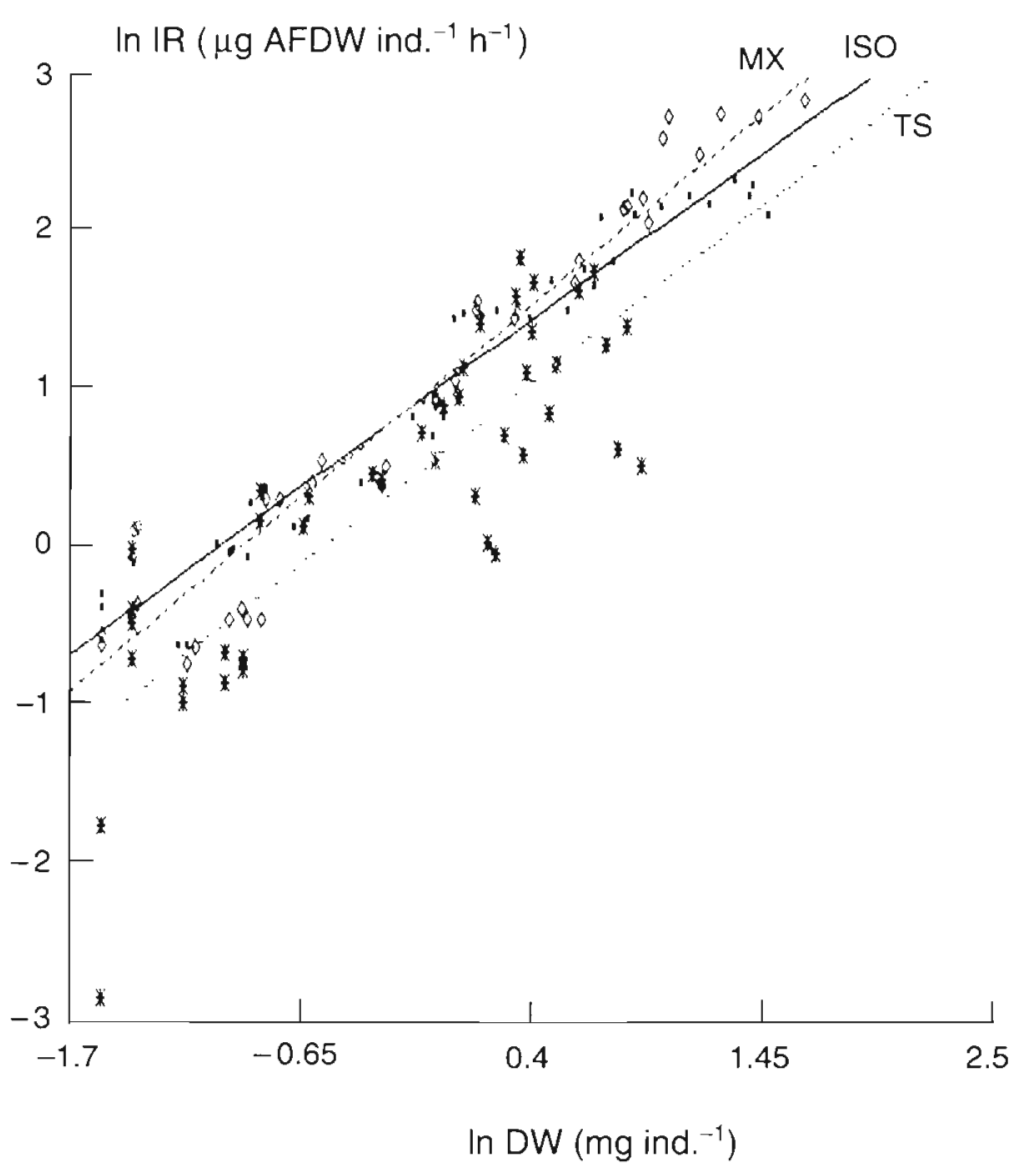

Fig. 5. Venerupis pullastra. Regression lines fitted between ingestion rates and individual dry weight of spat. Ingestion rates are expressed as $\mu \mathrm{g}$ AFDW ind ${ }^{-1} \mathrm{~h}^{-1}$ and dry weights as $\mathrm{mg}$ ind. ${ }^{-1}$. (0) Isochrysis galbana; (*) Tetraselmis suecica; $(\diamond)$ mixture-fed spat 
Table 4. Biochemical composition of the phytoplankton used as food for the clams. "Standardized percentages

\begin{tabular}{|c|c|c|c|c|c|c|c|}
\hline & $\begin{array}{l}\text { Ash } \\
\% \mathrm{DW}\end{array}$ & \multicolumn{2}{|c|}{ Carbohydrates } & \multicolumn{2}{|c|}{ Proteins } & \multicolumn{2}{|c|}{$\begin{array}{l}\text { Lipids } \\
\% \text { DW } \% \text { AFDW }\end{array}$} \\
\hline ISO & 15.44 & $\begin{array}{l}20.23 \\
23.87^{\circ}\end{array}$ & $\begin{array}{l}23.92 \\
28.22^{\circ}\end{array}$ & $\begin{array}{l}23.60 \\
27.09^{\circ}\end{array}$ & $\begin{array}{l}27.91 \\
33.69^{\circ}\end{array}$ & $\begin{array}{l}27.84 \\
32.85^{\circ}\end{array}$ & $\begin{array}{l}32.92 \\
38.84^{\circ}\end{array}$ \\
\hline TS & 24.66 & $\begin{array}{l}20.50 \\
38.60^{\circ}\end{array}$ & $\begin{array}{l}27.21 \\
51.24\end{array}$ & $\begin{array}{l}13.48 \\
25.38^{\circ}\end{array}$ & $\begin{array}{l}17.89^{\circ} \\
33.69^{\circ}\end{array}$ & $\begin{array}{r}6.03 \\
11.35^{\circ}\end{array}$ & $\begin{array}{r}8.00 \\
15.07^{\circ}\end{array}$ \\
\hline $\mathrm{MX}$ & 20.05 & $\begin{array}{l}20.37 \\
31.24\end{array}$ & $\begin{array}{l}25.57 \\
39.73^{\circ}\end{array}$ & $\begin{array}{l}18.54 \\
26.61^{\circ}\end{array}$ & $\begin{array}{l}22.90 \\
33.31^{\circ}\end{array}$ & $\begin{array}{l}16.94 \\
22.10^{\circ}\end{array}$ & $\begin{array}{l}20.46 \\
26.96^{\circ}\end{array}$ \\
\hline
\end{tabular}

tent of the spat depending on the diet. Thus, protein percentage of TS spat was lower than for the other diets. However, no significant differences were detected in the protein content between ISO and MX spat. Standardization of the biochemical percentages also allowed us to detect significant differences $(p<0.05)$ in the lipid content of the spat. It is assumed that the proportion of the components in the organic matter undetected by the analytical methods is the same as in

The sum of the gross biochemical components did not correspond with the total organic matter estimated by ashing, so biochemical percentages were standardized - noted by an asterisk in the table - in such a way that the sum of the evaluated components was considered the total organic content of the samples. In Fig. 6 percentages of ash-free dry weight of biochemical constituents of the diets are shown together with the percentages of the organic matter not detected by the analysis,

Gross biochemical composition of spat at the beginning and end of the experiment is detailed in Table 5. Increases in the biochemical composition during the experimental period are shown in Fig. 7. The increase in proteins for ISO- and MX-fed spat was twice the increase in lipids or carbohydrates. However, there was a substantial increase in lipids - higher even than the protein increase - for TS-fed spat.

Statistical analysis applied to angular transformations of the biochemical percentages shows that there were significant differences $(p<0.05)$ in protein con-

\section{(\%)AFDW}

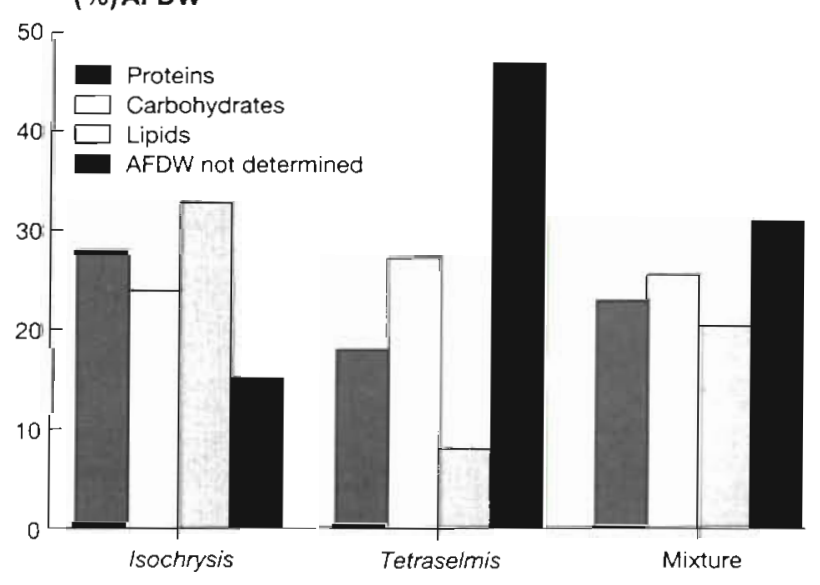

Fig. 6. Venerupis pullastra. Gross biochemical composition of the phytoplankton used as food for spat. Mixed diet composition was considered as the mean value of the 2 single-species diets. AFDW not determined by the analytical methods used is also shown the organic matter analyzed. Spat growth differences between diets are highly correlated with the protein and lipid content of the spat. Protein content shows a positive correlation (Table 6) with spat growth, so that in those cultures in which growth rate was high, spat protein content was also high By contrast, the correlation coefficient detected between growth and lipid content was negative, meaning that low growth rates were associated with high body lipid levels.

Differences in the protein conversion indices were detected between diets (Table 7 ). The protein conversion index was high (i.e. $76 \%$ and $67 \%$ for $\mathrm{MX}$ and ISO diets, respectively) and promoted good growth, whereas for TS the protein conversion index was substantially lower $(43 \%)$.

\section{DISCUSSION}

Isochrysis galbana is a good food whereas the nutritive value of Tetraselmis suecica is moderate in the culture of Venerupis pullastra spat. Better results can be obtained with a mixture of both microalgal species.

Traditionally, it has been considered that the following factors are responsible for the nutritive value of the microalgae species used as food for bivalves: cell size, digestibility, toxicity and biochemical composition (Webb \& Chu 1983). With regard to algal cell size, the species studied show considerable differences: Tetraselmis suecica cells are notably larger than Isochrysis galbana cells, with mean cell diameters of $7.64( \pm 0.36) \mu \mathrm{m}$ and $4.00( \pm 0.09) \mu \mathrm{m}$, respectively; mean cell volumes were $249.85( \pm 33.91)$ and 35.07 $( \pm 2.66) \mu \mathrm{m}^{3}$ respectively. However, both cell sizes can be retained efficiently by the filtration mechanism of molluscs (Jørgensen 1990).

Growth differences observed between treatments can be explained partly by differences in ingestion rates. In fact, specific ingestion rates were slightly higher for MX-fed spat, followed by ISO, and were significantly lower in TS-fed spat. Ingestion of Isochrysis galbana was higher than that of Tetraselmis suecica 
Table 5. Venerupis pullastra. Biochemical composition of spat fed with the 3 diets. Carbohydrates, proteins and lipids are expressed as \% of dry and ash-free dry weights and as $\mathrm{mg}$ ind.- ${ }^{-1}$ 'Standardized percentages

\begin{tabular}{|c|c|c|c|c|c|c|c|c|c|c|}
\hline & \multirow{2}{*}{$\begin{array}{c}\text { Ash } \\
\% \text { DW }\end{array}$} & \multicolumn{3}{|c|}{ Carbohydrates } & \multicolumn{3}{|c|}{ Proteins } & \multicolumn{3}{|c|}{ Lipids } \\
\hline & & $\% D W$ & $\%$ AFDW & $\operatorname{mg}$ ind. ${ }^{-1}$ & $\% \mathrm{DW}$ & $\%$ AFDW & $\mathrm{mg}$ ind.$^{-1}$ & $\% \mathrm{DW}$ & $\% A F D W$ & $\mathrm{mg}$ ind $\mathrm{d}^{-1}$ \\
\hline \multirow[t]{2}{*}{ Initial. } & 84.74 & 1.36 & 8.91 & 0.0029 & 3.54 & 23.20 & 0.0074 & 2.01 & 13.17 & 0.0042 \\
\hline & & $3.00^{\circ}$ & $19.68^{\circ}$ & $0.0063^{\circ}$ & $7.82^{\circ}$ & $51.24^{\circ}$ & $0.0164^{\circ}$ & $4.44^{\circ}$ & $29.09^{\circ}$ & $0.0093^{\circ}$ \\
\hline \multirow[t]{2}{*}{ ISO } & 72.60 & 2.56 & 9.32 & 0.114 & 11.73 & 42.89 & 0.523 & 4.23 & 15.65 & 0.186 \\
\hline & & $3.83^{\circ}$ & $13.89^{\circ}$ & $0.171^{\circ}$ & $17.47^{\circ}$ & $63.58^{\circ}$ & $0.782^{\circ}$ & $6.11^{\circ}$ & $22.54^{\circ}$ & $0.271^{\circ}$ \\
\hline \multirow[t]{2}{*}{ TS } & 76.87 & 1.78 & 7.80 & 0.044 & 5.30 & 22.83 & 0.131 & 4.96 & 21.69 & 0.121 \\
\hline & & $3.41^{\circ}$ & $14.82^{\circ}$ & $0.084^{\circ}$ & $10.24^{\bullet}$ & $43.89^{\circ}$ & $0.254^{*}$ & $9.50^{\circ}$ & $41.29^{\circ}$ & $0.234^{\circ}$ \\
\hline \multirow[t]{2}{*}{$\mathrm{MX}$} & 75.86 & 2.05 & 8.44 & 0.138 & 11.23 & 46.26 & 0.756 & 2.92 & 12.09 & 0.199 \\
\hline & & $3.05^{\circ}$ & $12.63^{\circ}$ & $0.208^{\circ}$ & $16.72^{\circ}$ & $69.16^{\circ}$ & $1.138^{\circ}$ & $4.39^{\circ}$ & $18.23^{\circ}$ & $0.303^{\circ}$ \\
\hline
\end{tabular}

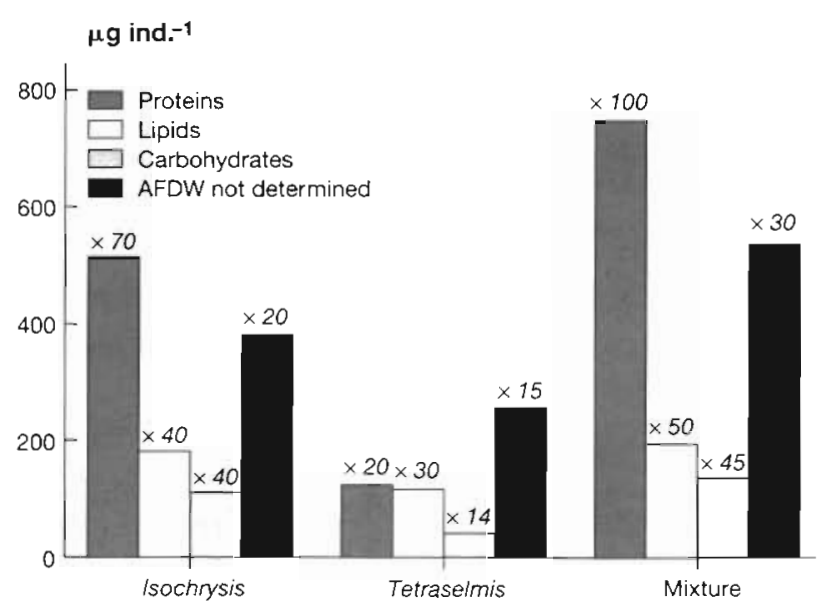

Fig. 7. Venerupis pullastra. Increases of the biochemical components of spat fed on 3 diets during the 4 wk of the experiment. AFDW not determined by the analytical methods used is also shown

cells in MX. Although there is a different ingestion depending on the microalgal species, this fact cannot completely explain the differences in growth. The proportion of food ingested is lower for the TS diet than for the other diets. However, the proportion of ingested food used for growth is also lower (Fig. 8a, b, c).

Digestibility of phytoplankton cells can be another factor determining growth. Epifanio (1979) explains the limited nutritive value of Tetraselmis suecica to molluscs by the difficulty of digestion of the complex polysaccharides and protein composing the theca of this microalga. In a later study, Romberger \& Epifanio (1981) determined assimilation efficiencies of different microalgal species supplied as single and mixed diets for Crassostrea virginica juveniles and described an assimilation efficiency of $7 \%$ for $T$, suecica cells and $74 \%$ for Isochrysis galbana. However, we found higher assimilation efficiencies (calculated from growth and estimated respiration costs) for $T$. suecica cells (nearly $60 \%$ ) although this value was slightly lower than the efficiency of $I$. galbana cells $(70 \%)$. We did not observe an increase in assimilation of cells when they were supplied as a mixed diet.

Another possible explanation for differences in the nutritive value of microalgal species is related to their biochemical composition and their adequacy for the nutritional requirements of bivalves.

Analyses of the phytoplankton cultures used in these experiments (Fig. 5) show that Tetraselmis suecica cells have a lower protein content $(18 \%$ of organic matter, unstandardized value) than Isochrysis galbana (28\%), i.e. almost $40 \%$ less. Flaak \& Epifanio (1978) calculated a protein requirement for Crassostrea virginica juveniles (>2.5 cm length) of $20 \%$ of diet dry weight, a value slightly higher than the protein content of the $T$. suecica cultures used in our experiment. There are no data in the literature on protein requirements of mollusc spat of the size used in this work (1.4 $\mathrm{mm}$ ); however, such requirements should be higher than those reported by Flaak \& Epifanio since growth rates are higher for this spat size. The considerably higher lipid content of the $I$. galbana cultures (more than $30 \%$ of the organic matter) in relation to T. suecica cultures $(8 \%)$ could also influence spat growth. Experiments carried out by Holland \& Spencer (1973) and Holland \& Hannant (1974) demostrated that

Table 6. Venerupis pullastra. Correlation analysis between biochemical composition (standardized percentage of the ash-free dry weight) and growth (dry weight; $\mathrm{mg}_{\text {ind }}^{-1}$ ) of the spat at the end of the experiment

\begin{tabular}{|lcccc|}
\hline Growth index & $\begin{array}{c}\text { Biochemical } \\
\text { component }\end{array}$ & $\begin{array}{c}\text { Correlation } \\
\text { coefficient }(\mathrm{r})\end{array}$ & $\begin{array}{c}\text { Significance } \\
\text { level }(\mathrm{p})\end{array}$ & $\mathrm{n}$ \\
\hline Dry weight & Carbohydrates & -0.587 & 0.220 & 6 \\
Dry weight & Protein & 0.855 & 0.030 & 6 \\
Dry weight & Lipids & -0.827 & 0.042 & 6 \\
\hline
\end{tabular}


Table 7. Venerupis pullastra. Protein conversion indices of spat (mg ind.$^{-1}$ ). $\Delta$ : protein increases during the experimental period; Ing: ingestion of dietary protein during the same time $C I$ : conversion indices

\begin{tabular}{|lccc|}
\hline & $\Delta$ & Ing & $C I$ \\
\hline ISO & 0.51 & 0.76 & $67 \%$ \\
TS & 0.12 & 0.28 & $43 \%$ \\
MX & 0.75 & 0.99 & $76 \%$ \\
\hline
\end{tabular}

(1973) and Holland \& Hannant (1974) demostrated that both larvae and early spat make use of lipids as the main energy reserves, whereas adults accumulate energy as glycogen. The carbohydrate contents of the 2 microalgal species are very similar - about $25 \%$ of the organic matter.

That the total organic matter found by biochemical analysis did not correspond with that determined by ashing has been observed by other authors (Heral \& Deslous-Paoli 1983). His \& Maurer (1988) consider that organic matter not detected by analytical methods consists of proteins not detected by the Lowry method. Present results show that the proportion of organic matter not detected is higher in Tetraselmis suecica cultures $(45 \%)$, so considering its poor nutritive value it can be supposed that the components undetectable by analytical procedures are refractory to the bivalves' enzymes.

Another difference in the biochemical composition of the 2 algal species is related to fatty acid content. Isochrysis galbana shows considerable amounts of 2 polyunsaturated fatty acids regarded as essential for certain species of molluscs, 20:5 03 and 22:6w3, whereas Tetraselmis suecica is deficient in the latter (Albentosa et al. unpubl.). Langdon \& Waldock (1981) proved that these fatty acids are essential for Crassostrea gigas spat by using a combination of algal diets deficient in 20:5 13 and/or 22:6w3 fatty acids, and adding supplements of microencapsulated lipids. Growth of $T$. suecica fed spat was improved by adding supplements of 22:6w3. According to our results (Albentosa et al. unpubl.), the fatty acid composition of Venerupis pullastra spat reflected that of the diet. I. galbana-fed spat showed a high 22:6w3 content, exactly $8.5 \%$ of the total fatty acids. By contrast, the proportion of this fatty acid was very low $(0.34 \%)$ when the diet used was $T$. suecica. Spat fed on the mixture had an intermediate content $(3.8 \%)$ of $22: 6 \mathrm{w} 3$. These results suggest that $V$. pullastra spat is not able to synthesize 22:6w3 from dietary 20:5w3

Gross biochemical composition of spat was also influenced by diet composition, mainly with regard to protein and lipid content. Increases in the protein content of the spat were double the lipid increases for the

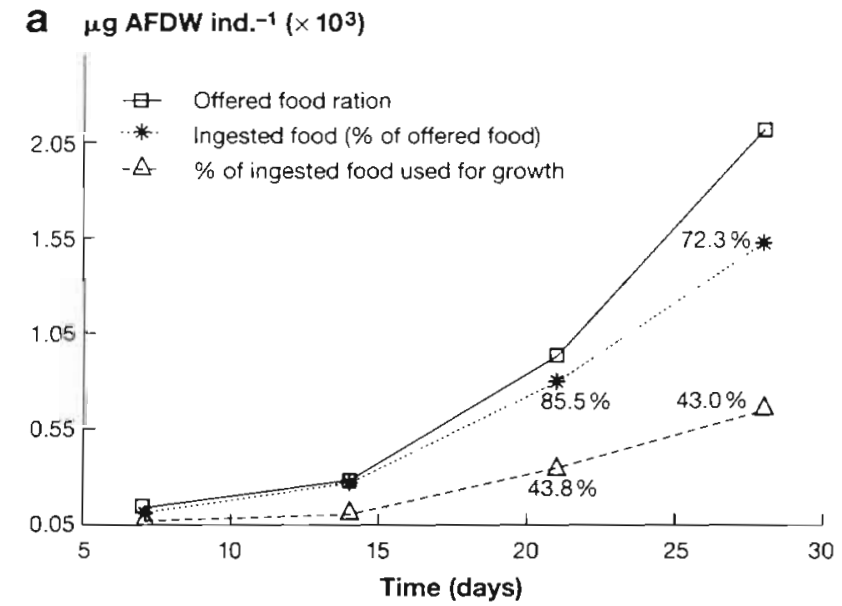

b $\mu$ g AFDW ind. ${ }^{-1}\left(\times 10^{3}\right)$

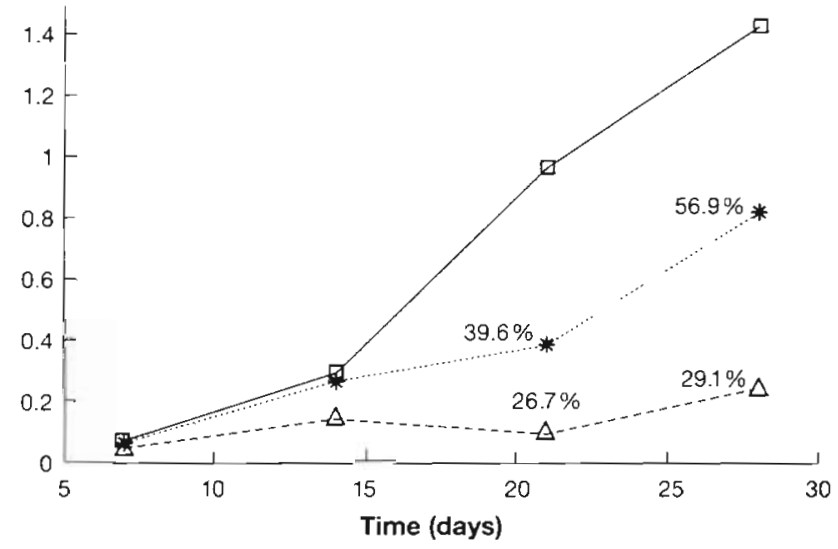

C $\mu g$ AFDW ind.-1 $\left(\times 10^{3}\right)$

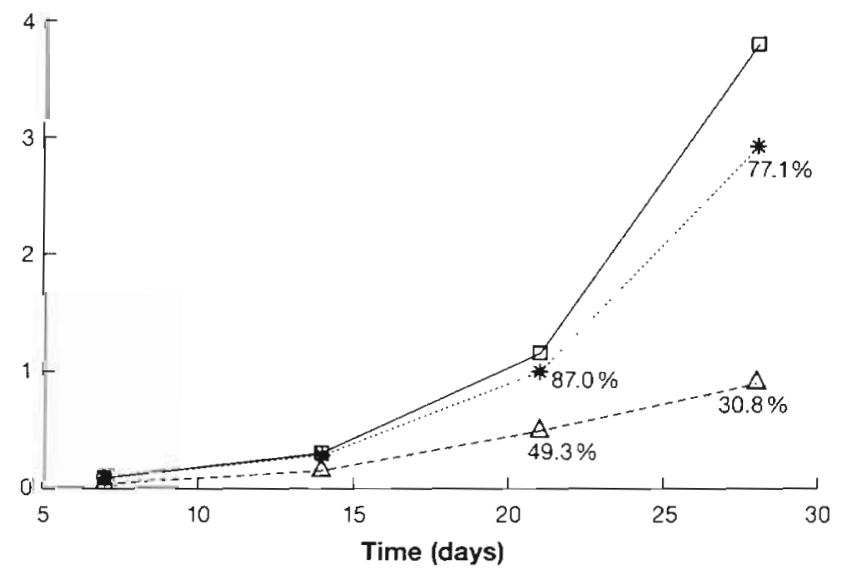

Fig. 8. Venerupis pullastra. Percentages of food utilization by spat fed with (a) Isochrysis galbana, (b) Tetraselmis suecica and (c) the mixed diet

growth-promoting diets (ISO and MX) (Fig. 7), whereas protein increase was lower than lipid increase for TS-fed spat. It seems that TS-fed spat cannot utilize dietary lipids properly. Thus, almost all lipids ingested are immobilized in the body tissues and proteins have 
to be used as energetic combustibles. Consequently growth is limited. This situation becomes more critical because the protein content in TS diet is the lowest. With the high-nutritive-value diets (ISO and MX), lipids ingested are optimally used as energetic fuels and protein can be retained for synthesis of new body structures.

The slight increase of spat growth rate with the mixed diet compared to the Isochrysis galbana diet cannot be explained by our work. The mixture of the 2 algal species may supply further micronutrients (not evaluated in our experiment) which may be responsible for growth increase.

We consider that the nutritive quality of microalgal species does not depend on any particular factor but rather on the sum of total nutritive properties such as diet acceptability, digestibility and biochemical composition.

Acknowledgements. We thank. C. Fernández Pena for her helpful technical assistance in the algal and spat cultures and to L. Nieto in the biochemical analysis. This work was funded by CICYT-CSIC-IEO project I+D number MAR90-0821-CO2-01.

\section{LITERATURE CITED}

Bligh, E. G., Dyer, W. J. (1959). A rapid method of total lipid extraction and purification. Can. J. Biochem. 37: 911

De La Higuera, M., Murillo, A., Zamora, S., Varela, G. (1977). The influence of dietary fat levels on protein utilization by the trout (Salmo gairdneri). Comp. Biochem. Physiol. 56A: $37-41$

De Pauw, N. (1981). Use and production of microalgae as food for nursery bivalves. In: Claus, C., De Pauw, N., Jaspers, E. (eds.) Nursery culturing of bivalve molluscs. European Mariculture Society, Spec. Publ. 17, Bredene, p. 35-69

Enright, C. T., Newkirk, G. F., Craigie, J. S., Castell, J. D. (1986a). Evaluation of phytoplankton as diets for juvenile Ostrea edulis L. J. exp. mar. Biol. Ecol. 96: 1-13

Enright, C. T., Newkirk, G. F., Craigie, J. S., Castell, J. D. (1986b). Growth of juvenile Ostrea edulis L. fed Chaetoceros gracilis of varied chemical composition. J. exp. mar. Biol. Ecol. 96: 15-26

Epifanio, C. E. (1979). Growth in bivalve molluscs: nutritional effects of two or more species of algae in diets fed to the American oyster Crassostrea virginica (Gmelin) and the hard clam Mercenaria mercenaria (L.). Aquaculture 18 $1-12$

Epifanio, C. E., Ewart, J. (1977). Maximum ration of four algal diets for the oyster Crassostrea virginica Gmelin. Aquaculture 11: 13-29

Fernández-Reiriz, M. J., Pérez-Camacho, A., Ferreiro, M. J., Blanco, J., Planas, M., Campos, M. J., Labarta, U. (1989). Biomass production and variation in the biochemical profile (total protein, carbohydrates, RNA, lipids and fatty acids) of 7 species of marine microalgae. Aquaculture 83 : $17-37$
Flaak, A. R., Epifanio, C. E. (1978). Dietary protein levels and growth of the oyster Crassostrea virginica. Mar. Biol. 45: $157-163$

Folch, J., Lees, M., Sloane-Stanley, G. G. (1957). A simple method for the isolation and purification of total lipids from animal tissues. J. biol. Chem. 226: 497

Heral, M., Deslous-Paoli, J. M. (1983). Valeur énergétique de la chair de l'huitre Crassostrea gigas estimée par mesures microcalorimétriques et par dosages biochimiques. Oceanologica Acta 6(2): 193-199

His, E., Maurer, D. (1988). Shell growth and gross biochemical composition of oyster larvae (Crassostrea gigas) in the field. Aquaculture 69: 185-194

Holland, D. L., Hannant, P. J. (1974). Biochemical changes during growth of the spat of the oyster, Ostrea edulis L. J. mar. biol. Ass. U.K. 54: 1007-1016

Holland, D. L., Spencer, B. E. (1973). Biochemical changes in fed and starved oysters, Ostrea edulis L. during larval development, metamorphosis and early spat growth. J. mar. biol. Ass. U.K. 53: 287-298

Jørgensen, C. B. (1990). Bivalve filter feeding: hydrodynamics, bioenergetics, physiology and ecology. Olsen \& Olsen, Fredensborg

Langdon, C. J., Waldock, M. J. (1981). The effect of algal and artificial diets on the growth and fatty acid composition of Crassostrea gigas spat. J. mar. biol. Ass. U.K. 61: 431-448

Lowry, O. H., Rosebrough, N. J., Fair, A. L. (1951). Protein measurement with the pholin-phenol reagent. J. biol. Chem. 193: 265-275

Marsch, J. B., Weinstein, D. B. (1966). Simple charring method for the determination of lipids. J. Lipid Res. 7: 574-576

Pérez Camacho, A., Román, G., Torre Cervigón, M. (1977). Experiencias en cultivos de larvas de tres especies de moluscos bivalvos: Venerupis pullastra (Montagu), Venerupis decussata (Linnaeus) y Ostrea edulis (Linnaeus). Bol. Inst. Esp. Oceanogr. III, 235: 7-62

Romberger, H. P., Epifanio, C. E. (1981). Comparative effects of diets consisting of one or two algal species upon assimilation efficiencies and growth of juvenile oysters, Crassostrea virginica (Gmelin). Aquaculture 25: $77-87$

Strickland, J. D., Parsons, T. R. (1968). A practical handbook of seawater analysis. Bull. Fish. Res. Bd Can. 167

Walne, P. R. (1965). Observations on the influence of food supply and temperature on the feeding and growth of the larvae of Ostrea edulis L. Fish. Invest. Minist. Agric. Fish. Food (GB) Ser. II Salmon Freshwater Fish., XXIV: 1

Walne, P. R. (1966). Experiments in the large-scale culture of the larvae of Ostrea edulis L. Fish. Invest. Minist. Agric. Fish. Food (GB) Ser. II Salmon Freshwater Fish., XXV: 4

Walne, P. R. (1970). Studies on the food value of nineteen genera of algae to juvenile bivalves of the genera Ostrea, Crassostrea, Mercenaria and Mytilus. Fish. Invest. Minist. Agric. Fish. Food (GB) Ser. II Salmon Freshwater Fish., XXVI: 5

Webb, K. L., Chu, F. E. (1983). Phytoplankton as a food source for bivalve larvae. In: Pruder, G. D., Langdon, C. J., Conklin, D. E. (eds.) Proceedings of the 2nd International Conference on Aquaculture Nutrition, World Mariculture Society, p. 272-291

Wikfors, G. H., Twarog, J. W., Ukeles, R. (1984). Influence of chemical composition of algal food sources on growth of juvenile oysters, Crassostrea virginica. Biol. Bull. 167 . $251-263$ 